\title{
IMPLEMENTASI METODE DJIKSTRA DALAM MENENTUKAN JARAK TERPENDEK PADA PENDISTRIBUSIAN BARANG PT. AKUR MAKMUR
}

\author{
Haerul Anwar ${ }^{1 *}$, Randi kurnia Sandi², Adi Sukmana ${ }^{3}$ \\ 1,2,3Fakultas Teknik Program studi Teknik industri, Universitas Widyatama, \\ Jl.Phh Mustafa no.59 Bandung 40124 \\ *email: anwarchoirul695@gmail.com
}

\begin{abstract}
PT. Akur Makmur needs the shortest distance solution for the process of distributing goods from the Central Warehouse distribution to branches that need in the City quickly, this solution is needed to avoid congestion and speed in distributing goods, and djikstra in accordance with one of the methods used to renew the shortest path so that the goods arrive on time. PT. Akur Makmur can minimize the costs and time needed to distribute goods. The problems in this study are (1) How does PT. Make graphs in the form of graphs (2) How PT. Accurately determine the shortest distance using the djikstra method (3) Determine the costs that can be resolved if using the calculation results with the djikstra method. In this study, taking real data in the field, then measuring the distance and time to use Google Maps facilities, then measuring the shortest distance using the djikstra algorithm, then compiling the route of the data obtained and looking for the shortest path using the Djikstra Algorithm. Based on the results of this study, it can be concluded (1) determining the trajectory in the form of a graphical algorithm (3) comparing the weight of each trajectory distance traversed in the distribution of goods (3) determining the shortest route to be used in the distribution of goods. Advice can be given to PT. Akur Makmur is as a comparison and alternative to the shortest path choice in the distribution of goods.
\end{abstract}

Keywords: Djikstra, Shortest path

\section{Pendahuluan}

Sebagai salah satu perusahaan yang sedang berkembang pesat di kota bandung PT. Akur Makmur akan membuka cabang baru yaitu di daerah cikutra, maka perlu menentukan lokasi untuk mengembangkan usahanya dengan memperhitungkan jarak tiap lokasi guna memperlancar pendistribusian barang. sebagai langkah awal perusahaan akan merumuskan rute yang akan dijadikan rute Terpendek dengan mempertimbangkan waktu dan kecepatan pengiriman.

Alogarima Djikstra digunakan sebagai salah satu referensi yang akan digunakan untuk menguji lintasan yang akan dijadikan rute untuk pengiriman barang berupa graph dan alternatif rute yang bisa digunakan.

Dalam jurnal Yao, Biyuan dkk, (2016, 139) Dijkstra algorithm is well recognized as an efficient technique to address shortest path problem. It could be adopted to compute the distance among one node to the rest, thus enable to calculate the optimized results, which is a greedy algorithm to single-source shortest path problem. Menurut kutipan diatas Algoritma
Dijkstra ini juga diakui sebagai teknik yang efisien untuk mengatasi masalah lintasan terpendek. Sehingga dapat menghitung jarak antara satu node ke yang lain, serta memungkinkan untuk menghitung hasil optimal, yang merupakan perhitungan untuk masalah lintasan terpendek Sehingga dapat menghitung jarak antara satu node ke yang lain, serta memungkinkan untuk menghitung hasil paling optimal, yang merupakan perhitungan untuk masalah lintasan terpendek.

Hasil dari penelitian ini diharapkan menjadi solusi untuk jalur pendistribusian barang pada PT. Akur makmur.

\section{Landasan Teori}

\subsection{Definisi Alogaritma Djikstra}

Algoritma Dijkstra dikembangkan oleh ilmuwan Belanda Edsger Dijkstra pada tahun 1959. Dalam jurnal Miglani Vanita, dkk (2016: 5303) Dijkstra's Algorithm is a search algorithm that computes the single source shortest path problem for a graph with nonnegative edge path costs, producing a shortest path tree. Menurut kutipan diatas Algoritma Dijkstra adalah algoritma 
pencarian yang menghitung lintasan terpendek menggunakan grafik dengan bobot non-negatif, sehingga dapat menemukan jalur terpendek.

\section{Metode Penelitian}

Secara umum Alogaritma Djikstra adalah alogaritma dalam teori graph yang dapat digunakan untuk mencari jarak dan lintasan terpendek untuk sebuah graph terhubung berbobot. Utnutk mencari lintasan terpendek dari Distribution Center ke lokasi pengiriman barang digunakan Alogaritma Djikstra dengan langkah-langkah sebagai berikut :

a. Mencari data pengiriman dari Distribution Center ke lokasi pengiriman

b. Pengukuran jarak tempuh mengunakan Fasilitas google maps

c. Menyusun data jarak yang diperoleh mengunakan metode graph

d. Melakukan perbandingan jarak pendistribusian

e. Menjelaskan hasil dari perhitungan alogaritma djikstra

\section{Hasil Dan Pembahasan}

Berdasarkan data yang peneliti Dapat dari PT. Akur makmur alur proses pendistribusian barang digambarkan dalam bentuk peta, kemudian peneliti mengambil data melaui google map baik jarak dan waktu berdasarkan waktu normal tanpa kemacetan jalur tersebut peneliti asumsikan/ditandai berdasarkan titik lokasi jalur yang dilalui dalam dalam bentuk abjad alfabet yang mewakili nama lokasi berdasarkan gambaran peta berikut :

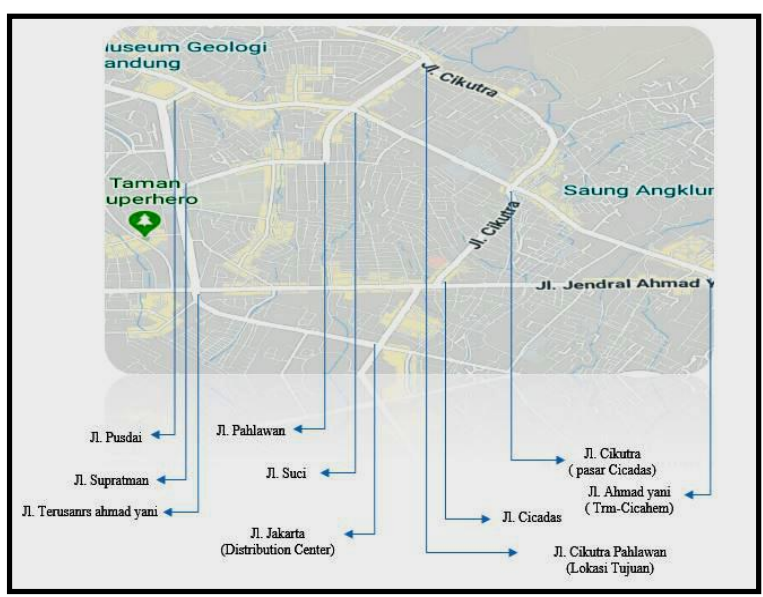

Gambar 1. Peta pendistribusian barang

Berdasarkan Peta diatas jalur yang akan dilalui dalam pendistribusian barang terdapat 10 jalan yang akan dilalui dari titik asal (Distribution Center) yang diasumsikan dengan $\mathrm{A}$, ke titik origin (titik Tujuan) yang diasumsikan dengan $\mathrm{J}$, peneliti menyajikan data dalam bentuk tabel agar mempermudah penyebutan nama lokasi dan asumsikan sebagai berikut :

Tabel 1. Daftar Asumsi Lokasi

\begin{tabular}{clc}
\hline No & \multicolumn{1}{c}{ Nama } & Diasumsikan \\
\hline 1 & Jl. Jakarta (Distribution & A \\
& Center) & B \\
2 & Jl. Terusan ahmad yani & C \\
3 & Jln. Cicadas & \\
4 & Jl. Ahmad yani (Jl. & D \\
& Ahmad yani & \\
& (Trm-Cicahem) & $\mathrm{E}$ \\
5 & Jl. Cikutra (Pasar & $\mathrm{F}$ \\
& Cicadas) & $\mathrm{G}$ \\
6 & Jl. Supratman & $\mathrm{H}$ \\
7 & Jl. Pahlawan & $\mathrm{I}$ \\
8 & Jl. Suci & $\mathrm{J}$ \\
9 & Jl. Pusdai & Jl. Cikutra Pahlawan \\
\hline
\end{tabular}

Berdasarkan Peta dan data asumsi diatas dapat diambil jalur yang terhubung dan jarak antar titik pusat pendistribusian Jl. Jakarta (Distribution Center) yang diasumsikan (A) dan titik lokasi pengiriman Jl. Cikutra Pahlawan (Lokasi Tujuan) yang diasumsikan $(\mathrm{J})$, jarak dihitng dengan skala Meter (M) dan waktu tempuh pendistribusian barang dalam bentuk tabel diambil dari waktu normal tanpa kendala macet dalam hitungan menit (Minute) sebagai berikut :

Tabel 2. Jarak dan waktu

\begin{tabular}{cccc}
\hline No & $\begin{array}{c}\text { Jalur } \\
\text { Terhubung }\end{array}$ & $\begin{array}{c}\text { Jarak } \\
\text { /meter }\end{array}$ & $\begin{array}{c}\text { Waktu/ } \\
\text { Menit }\end{array}$ \\
\hline 1 & A-B & 900 & 12 \\
2 & A-C & 1.100 & 15 \\
3 & A-D & 1.200 & 16 \\
4 & B-C & 1.400 & 18 \\
5 & B-F & 900 & 12 \\
6 & C-D & 1.700 & 22 \\
7 & D-E & 1.700 & 22 \\
8 & C-E & 1.200 & 16 \\
9 & E-J & 2.000 & 26 \\
10 & E-H & 1.300 & 16 \\
11 & F-G & 1.500 & 19 \\
12 & F-I & 900 & 12 \\
13 & G-H & 500 & 7 \\
14 & I-J & 1.500 & 19 \\
15 & I-H & 1.100 & 15
\end{tabular}


Selanjutnya peneliti ilustrasikan data diatas dalam bentuk gambar alogaritma graph sebagai berikut :

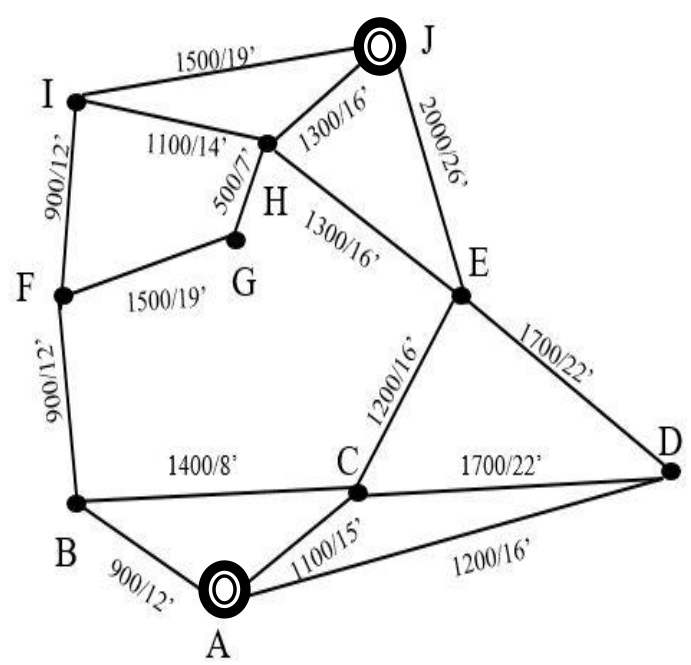

Gambar 2. Peta Alogaritma graph

Dari alogaritma diatas dapat disimmpulkan bahwa terdapat beberapa jalur yang dapat dilalui dalam mendistribusikan barang tersebut, berikut adalah jalurnya :

Tabel 3. Jalur yang terhubung

\begin{tabular}{cccc}
\hline NO & $\begin{array}{c}\text { Estimasi Jalur } \\
\text { Terhubung }\end{array}$ & $\begin{array}{c}\text { Jarak } \\
\text { /Meter }\end{array}$ & $\begin{array}{c}\text { Waktu } \\
\text { /Menit }\end{array}$ \\
\hline 1 & ABFIJ & 4200 & 5.5 \\
2 & ABFIHJ & 4500 & 85 \\
3 & ABFGHJ & 5100 & 75 \\
4 & ABCEJ & 5500 & 62 \\
5 & ABCEHJ & 6100 & 68 \\
6 & ACEJ & 4300 & 57 \\
7 & ACEHJ & 4900 & 63 \\
8 & ADEJ & 4900 & 64 \\
9 & ADEHJ & 5500 & 70 \\
10 & ABCDEHJ & 8300 & 96 \\
11 & ABCDEJ & 7700 & 90 \\
12 & ADCEJ & 6100 & 80 \\
13 & ADCEHJ & 670 & 86 \\
\hline
\end{tabular}

Setelah mendapatkan data estimasi jalur yang bisa dilalui, selanjutnya melakukan perhitungan jarak dan waktu dan memilih rute terpendek pendistribusian barang. Berikut adalah contoh perhitungan guna menentukan jarak dan waktu terpendek nya :

Rumus

$\mathrm{JA}=\operatorname{Jarak} 1+$ jarak $2+$ jarak $3 \mathrm{dst}=\ldots \ldots . . . . . . \mathrm{km}$

$\mathrm{JW}=\mathrm{W} 1+\mathrm{W} 2+\mathrm{W} 3 \mathrm{dst}=\ldots \ldots . . \mathrm{Menit} / \ldots \ldots \ldots . . \mathrm{jam}$

Contoh perhitungan

Jalur alternatif : A-B-F-I-J

Jarak alternatif $(900+900+900+1500)=4200 \mathrm{~m} / 4.2$

$\mathrm{Km}$

Jarak waktu $(12+12+12+19) 55$ menit

Dari perhitungan diatas didapatkan hasil jarak 4200 meter/ $4.2 \mathrm{~km}$ dapat ditempuh dengan waktu 55 menit dengan kondisi normal.

\section{Kesimpulan}

Berdasarkan data dari pembahasan diatas dapat dapat disimpulkan sebagai berikut :

1. Alogaritma Djikstra terbukti efektif untuk pencarian rute terpendek untuk jalur pendistribusian barang PT. Akur makmur sehingga dapat memperpendek jalur pengiriman barang dengan memetakan alur proses pendistribusian dengan bantuan Fasilitas google map baik jarak maupun waktu dengan asumsi waktu normal tanpa kemacetan.

2. Menemukan jarak terpendek pengiriman barang dengan metode alogaritma graph berdasarkan data jarak dan waktu yang diperoleh dari dukungan aplikasi google maps sehingga dapat mempermudah pengelompokan jalur yang dapat dilalui.

3. Diperoleh jarak estimasi jalur yang dapat dilalui sebanyak 13 jalur, dengan rentang waktu tercepat adalah melalui jalur A-B-F-I-J dengan jarak 4200/4.2 km dengan waktu tempuh 55 menit, dan jarak terjauh melalui jalur A-D-C-E-H-J dengan jarak 6700/6.7 km dengan waktu tempuh 86 menit

\section{Daftar Referensi}

Budayasa 1 ketut. 2007. Teori graph dan Aplikasinya. Surabaya : Unesa University press

Miglani. Vanita. 2016. Intrusion Protection system in djikstra's alogarithm. International journal of Engineering Science and Computing. 6 (5): 5303-5306.

Yao, Biyun, dkk. 2016. Path Opt. imization Alghorithm based on graph Theory. Intesrnational journal of Grid and Distributed Computing, 9 (6): 137-148 
Zand, F Benjamin.1997. Three Fastest Shortest path alogarithms on real roadNetwork: Data structures and procedures. International Journal of Geographic and Decision Analysis, I (I) 70-82 